\title{
Pengaruh Kepemilikan Manajerial dan Komisaris Independen Terhadap Nilai Perusahaan Dengan CSR sebagai Variabel Mediasi
}

\author{
Yunita Ardianti ${ }^{1}$ \\ Akram ${ }^{2}$ \\ Surasni $^{3}$ \\ ${ }^{1,2,3}$ Fakultas Ekonomi dan Bisnis Universitas Mataram (Unram), NTB, Indonesia \\ e-mail : yunita.ardianti90yahoo.com Telp : 081917967224
}

\begin{abstract}
ABSTRAK
Penelitian bertujuan untuk mengetahui pengaruh kepemilikan manajerial dan komisaris independen terhadap nilai perusahaan melalui CSR. Penelitian dilakukan pada perusahaan pertambangan yang terdaftar di BEI periode tahun 2016-2017. Populasi pada penelitian adalah 82 perusahaan dan sampel penelitian berjumlah 36 dengan menggunakan metode purposive sampling.Penelitian menggunakan analisis jalur dengan alat analisis SPSS 23. Hasil penelitian menunjukkan bahwa kepemilikan manajerial dan komsaris independen berpengaruh terhadap CSR secara simultan. Kepemilikan manajerial, komisaris independen dan CSR tidak berpengaruh terhadap nilai perusahaan secara simultan. Kepemilikan manajerial tidak berpengaruh terhadap CSR dan nilai perusahaan secara parsial. Komisaris independen tidak berpengaruh terhadap CSR dan nilai perusahaan secara parsial.
\end{abstract}

Kata kunci : Nilai Perusahaan, CSR, Kepemilikan Manajerial, Komisaris Independen

\begin{abstract}
This study aims to determine the effect of managerial ownership and independent commissioners on corporate value through CSR. This research was conducted at mining companies listed on the Indonesia Stock Exchange for the period 2016-2017. The population in this study were 82 companies and 36 research samples using purposive sampling method. This study uses path analysis with SPSS 23. Analysis tools. The results of this study indicate that managerial ownership and independent commissions influence CSR simultaneously. Managerial ownership, independent commissioners and CSR have no effect on company value simultaneously. Managerial ownership does not partially affect CSR and companyvalue. Independent commissioners do not partially influence CSR and company value.
\end{abstract}

Keywords: Corporate Value, CSR, Managerial Ownership, Independent Commissioner

\section{PENDAHULUAN}

Perkembangan dunia bisnis saat ini mengalami kemajuan yang sangat pesat serta persaingan yang begitu ketat. Saat perusahaan semakin berkembang, maka tingkat kesenjangan sosial dan kerusakan lingkungan pun semakin tinggi Karena adanya aktivitas perusahaan yang tidak terkendali terhadap berbagai sumber daya untuk meningkatkan nilai perusahaan (Rosiana, 2013). Selain pihak yang terkait 
langsung dengan perusahaan, masyarakat dan lingkungan sekitar perusahaan pun merasakan dampak yang ditimbulkan oleh aktivitas operasi perusahaan.

Secara teoritis CSR merupakan inti dari etika bisnis dimana suatu perusahaan tidak hanya mempunyai kewajiban-kewajiban ekonomis dan legal kepada pemegang saham (shareholder) tetapi perusahaan juga mempunyai kewajiban terhadap pihak lain yang berkepentingan (stakeholders) dan tidak dapat lepas dari kenyataan bahwa suatu perusahaan tidak bisa hidup, beroperasi, bertahan dan memperoleh keuntungan tanpa bantuan dari berbagai pihak. Dengan demikian, CSR lebih menunjukkan kepedulian perusahaan terhadap kepentingan pihak-pihak lain secara lebih luas (stakeholders) daripada hanya sekedar kepentingan perusahaan itu sendiri (Putri dan Christiawan, 2014)

Pemerintah Indonesia sudah menyadari pentingnya tanggung jawab sosial dan lingkungan yang terbukti dengan telah dikeluarkannya UU No. 40 Tahun 2007 tentang perseroan terbatas pasal 66 ayat 2 bagian C yang menyatakan bahwa selain menyampaikan tanggung jawab perusahaan berupa laporan keuangan, perusahaan pun wajib melaporkan aktivitas tanggung jawab sosial dan lingkungannya. CSR mempunyai peran penting dalam meningkatkan nilai perusahaan sebagai hasil dari peningkatan penjualan perusahaan dengan cara melakukan berbagai aktivitas tanggung jawab sosial di lingkungan sekitar (Musa et al., 2013).

Ada beberapa faktor yang mampu mempengaruhi pengungkapan CSR antara lain kepemilikan manajerial dan komisaris independen yang tentunya dapat berpengaruh pada nilai perusahaan. Rawi dan Muchlish (2010) dalam 
penelitiannya menunjukkan jika suatu perusahaan memiliki kepemilikan saham manajer yang tinggi, perusahaan akan mengambil keputusan sesuai dengan kepentingan perusahaan yaitu dengan cara mengungkapkan informasi sosial yang seluas-luasnya dalam rangka untuk meningkatkan reputasi perusahaan.

Domash (2009) dalam Priantana dan Yustian (2011) menjelaskan kepemilikan manajerial adalah para pemegang saham yang juga berarti dalam hal ini sebagai pemilik dalam perusahaan dari pihak manajemen yang secara aktif ikut dalam pengambilan keputusan pada suatu perusahaan yang bersangkutan, yang biasanya dinyatakan sebagai presentase saham perusahaan yang beredar yang dimiliki oleh orang dalam perusahaan yaitu manajer, komisaris, dan direksi. Kepemilikan manajerial yang tinggi akan menyebabkan manajer mempunyai hak pengambilan keputusan yang tinggi pula sehingga manajer memiliki posisi yang kuat untuk mengendalikan perusahaan (Downes dan Goodman, 1999) termasuk keputusan tentang CSR. Jensen dan Meckling (1976) dalam Badjuri (2011) menemukan bahwa kepemilikan manajerial berhasil menjadi mekanisme untuk mengurangi masalah keagenan dari manajer dengan menyelaraskan kepentingan manajer dengan pemegang saham.

Pembentukan dewan komisaris merupakan salah satu mekanisme yang digunakan untuk memonitoring kinerja manajer. Semakin banyak dewan komisaris maka semakin baik pengawasan perusahaan dan nilai perusahaan pun meningkat (Kilat, suhadak dan nila, 2014).

Penelitian ini menggunakan perusahaan tambang sebagai objek penelitian karena berkaitan dengan lingkungan secara langsung. Berdasarkan latar belakang 
di atas, maka rumusan masalah sebagai berikut : 1. Apakah kepemilikan manajerial berpengaruh langsung terhadap CSR, 2. Apakah komisaris independen berpengaruh terhadap CSR, 3. Apakah kepemilikan manajerial berpengaruh terhadap nilai perusahaan, 4. Apakah komisaris independen berpengaruh terhadap nilai perusahaan, 5. Apakah CSR berpengaruh terhadap nilai perusahaan, 6 . Apakah kepemilikan manajerial dan komisaris independen berpengaruh terhadap nilai perusahaan melalui CSR

Adapun tujuan dari penelitian ini adalah untuk mengetahui bukti empiris dari pengaruh kepemilikan manajerial terhadap CSR, pengaruh komisaris independen terhadap CSR, pengaruh kepemilikan manajerial terhadap nilai perusahaan, komisaris independen terhadap nilai perusahaan, pengaruh CSR terhadap nilai perusahaan, dan pengaruh kepemilikan manajerial dan komisaris independen terhadap nilai perusahaan melalui CSR

Jensen dan Mackling (1976) menyatakan bahwa prinsip utama teori ini menyatakan adanya hubungan kerja antara pihak yang memberi wewenang ( pemilik/principal) dengan pihak yang menerima wewenang (manajer / agency).Kepemilikan dan pengendalian yang dipisah dalam suatu perusahaan merupakan salah satu faktor yang memicu timbulnya konflik kepentingan yang disebut dengan konflik keagenan. Konflik keagenan yang timbul antara berbagai pihak yang memiliki kepentingan berbeda-beda dapat menyulitkan dan menghambat perusahaan di dalam mencapai kinerja yang positif untuk menghasilkan nilai bagi perusahaan itu sendiri dan juga bagi shareholders 
Legitimasi merupakan sistem pengelolaan perusahaan yang berorientasi pada keberpihakan terhadap masyarakat (society), pemerintah individu dan kelompok masyarakat, Gray et al. (1996: 46) dalam Ahmad dan Rustiarini(2010). Untuk itu, sebagai suatu sistem yang mengutamakan keberpihakan atau kepentingan masyarakat. Teori legitimasi (Legitimacy theory) berfokus pada interaksi antara perusahaan dengan masyarakat.Teori ini menyatakan bahwa organisasi adalah bagian dari masyarakat sehingga harus memperhatikan normanorma sosial masyarakat karena kesesuaian dengan norma sosial dapat membuat perusahaan semakin legitimate.

Teori stakeholder mengatakan bahwa perusahaan bukanlah entitas yang hanya beroperasi untuk kepentingannya sendiri namun harus memberikan manfaat bagi stakeholdernya (Gantino, 2016). Fredman (1984) menunjukan bagaimana perusahaan mengelola hubungan dengan para pemangku kepentingannya serta membuat berbagai keputusan sehingga dapat meminimalisasi dampak buruk keputusan perusahaan terhadap para stakeholder. Sehingga antara perusahaan dan stakeholdernya memiliki hubungan yang saling membutuhkan

Kepemilikan manajerial merupakan jumlah lembar saham perusahaan yang dimiliki oleh pihak manajemen. Kepemilikan manajerial akan menyelesaikan masalah keagenan karena pihak manajemen juga memiliki saham perusahaan. Sehingga konflik kepentingan antara manajemen dan pemiliki selesai. Dengan kepemilikan manajerial, kedua pihak (principal dan agen) akan memiliki kepentingan yang sama. Semakin tinggi tingkat kepemilikan manajemen maka manajemen akan lebih termotivasi dan giat dalam rangka meningkatkan kinerja 
perusahaan dan memenuhi kepentingan para pemegang saham. Hal ini terjadi karena dirinya sendiri (manajemen) merupakan salah satu dari pemegang saham.

Komisaris independen merupakan sebuah badan dalam perusahaan yang biasanya beranggotakan dewan komisaris yang independen yang berasal dari luar perusahaan yang berfungsi untuk menilai kinerja perusahaan secara luas dan keseluruhan.Komisaris independen bertujuan untuk menyeimbangkan dalam pengambilan keputusan khususnya dalam rangka perlindungan terhadap pemegang saham minoritas dan pihak-pihak lain yang terkait.

Proporsi dewan komisaris independen (PDKI) merupakan prsentase jumlah komisaris independen dibandingkan dengan jumla keselurahan dewan komisaris. Komisaris independen juga bertanggung jawab untuk mendorong dijalankannya prinsip-prinsip GCG dalam perusahaan. Sehingga dengan adanya komisaris independen, pihak direksi akan menjalankan semua prinsip-prinsip GCG yang akan memberikan nilai tambah perusahaan dalam jangka panjang.

Corporate Social Responsibility (CSR) yaitu suatu bentuk aktivitas yang dilakukan perusahaan untuk meningkatkan ekonomi perusahaan sekaligus peningkatan kualitas hidup karyawan beserta keluarganya dan juga kualitas hidup masyarakat sekitar. Menurut Komisi Uni Eropa (2002) dalam Crowther dan Aras (2008)" CSR adalah sebuah konsep dimana perusahaan mengintegrasikan kepedulian sosial dan lingkungan pada operasi bisnis mereka dan dalam interaksi mereka dengan para pemangku kepentingan mereka pada dasar sukarela. Pramono (2017) menyatakan bahwa aktivitas CSR dapat memberikan banyak manfaat, seperti dapat meningkatkan citra dan daya tarik perusahaan di mata investor serta 
analis keuangan penjualan. Pengungkapan CSR merupakan proses pemberian informasi kepada kelompok yang berkepentingan tentang aktivitas perusahaan serta dampaknya terhadap sosial dan lingkungan.

Nilai perusahaan adalah sebuah nilai yang menunjukkan cerminan dari ekuitas dan nilai buku perusahaan, baik berupa nilai pasar ekuitas, nilai buku dari total utang dan nilai buku dari total ekuitas. Pelaksanaan GCG yang baik dan sesuai dengan peraturan yang berlaku, akan membuat investor memberikan respon positif terhadap kinerja perusahaan. Menurut Masri dan Marius (2017), nilai perusahaan merupakan persepsi investor terhadap perusahaan, yang sering dikaitkan dengan harga saham

Dalam penelitian ini nilai perusahaan diukur dengan menggunakanTobin's Q karena informasi yang diberikan oleh Tobin's Q dinilai paling baik. Tobin's Q menunjukkan bahwa perusahaan tidak terfokus pada investor dalam bentuk saham saja (Sukamulja, 2004 dalam Permanasari, 2010). Perusahaan yang memiliki Tobin's Q dengan nilai yang semakin tinggi menunjukkan bahwa prosfek pertumbuhan perusahaan semakin baik, karena investor akan mengeluarkan pengorbanan yang lebih untuk perusahaan yang memiliki nilai pasar aset yang lebih besar daripada nilai bukunya. Apabila nilai Q lebih kecil dari 1, berarti investasi dalam aktiva tidak menarik (Herawaty, 2008).

Berikut kerangka pemikiran penelitian ini antara lain : 


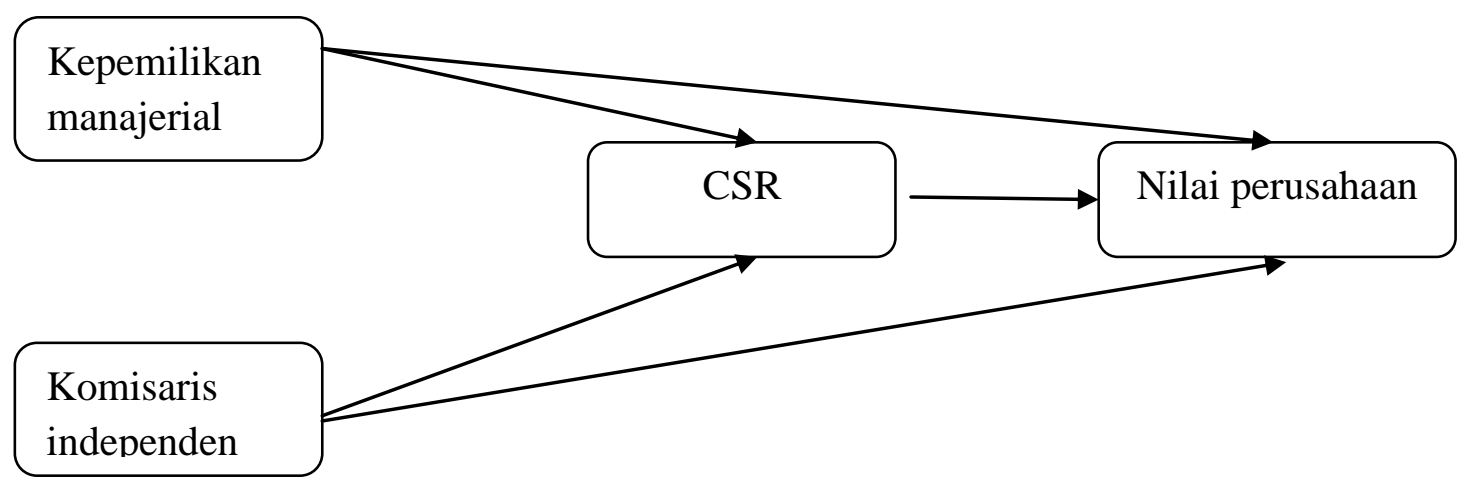

Gambar 1. Rerangka Konseptual

Sumber : Data diolah, 2017

Jika suatu perusahaan memiliki kepemilikan saham manajer yang tinggi, perusahaan akan mengambil keputusan sesuai dengan kepentingan perusahaan yaitu dengan cara mengungkapkan informasi sosial yang seluas-luasnya dalam rangka untuk meningkatkan reputasi perusahaan. Struktur kepemilikan lebih banyak berada di tangan manajer, maka manajer akan lebih leluasa dalam mengatur melakukan pilihan-pilihan metode akuntansi, serta kebijakan-kebijakan CSR perusahaan (Lindawati, 2015)

Beberapa penelitian yang menyatakan bahwa kepemilikan manajerial berpengaruh positif terhadap pengungkapan CSR diantaranya yaitu penelitian oleh Murwaningsari (2009) dan Herawaty (2008), Priantana dan Yustian (2011) yang menunjukkan bahwa kepemilikan manajerial berpengaruh terhadap pengungkapan CSR. Herawaty (2008) menyimpulkan bahwa kenaikan kepemilikan manajerial akan meningkatkan pengungkapan perusahaan terhadap CSR.

$\mathrm{H}_{1}$ : Kepemilikan manajerial berpengaruh terhadap CSR 
Peran komisaris independen sangat penting bagi jalannya perusahaan, karena komisaris independen akan menjadi pihak yang memonitor dan memberikan nasihat kepada direksi perusahaaan secara efektif. Selain itu, dewan komisaris independen memainkan peran penting dalam meningkatkan image perusahaan. Oleh karena itu, dewan komisaris independen dapat mendorong perusahaan untuk mengungkapkan informasi social dan lingkungannya, karena hal tersebut dapat meningkatkan image perusahaan dimata masyarakat.

$\mathrm{H}_{2}$ : Komisaris independen berpengaruh terhadap CSR

Kepemilikan manajerial adalah kepemilikan saham yang dimiliki oleh manajemen perusahaan (direksi dan komisaris) (Rachmad, 2012). Jensen dan Meckling (1976) mengatakan bahwa kinerja dan motivasi karyawan dapat ditingkatkan dengan adanya kepemilikan manajerial, hal ini disebabkan oleh manajer yang akan lebih memikirkan dengan matang setiap tindakan yang akan diambilnya. Oleh sebab itu, dugaan yang timbul dari kepemilikan manajemen yaitu akan memberikan nilai tambah bagi perusahaan (Amanti, 2012). Penelitian Barako et al (2006) menunjukkan nilai perusahaan dipengaruhi secara positif oleh kepemilikan manajerial.

$\mathrm{H}_{3}$ : Kepemilikan manajerial berpengaruh terhadap nilai perusahaan

Dewan komisaris independen adalah komisaris yang tidak mempunyai ikatan bisnis atau hubungan keluarga dengan pemegang saham maupun direksi (Rachmad, 2012).Kepentingan manajer dan pemegang saham dapat diselaraskan oleh adanya dewan komisaris, karena mereka mewakili mekanisme internal utama untuk mengawasi perilaku yang mengeksploitasi peluang atau keuntungan jangka 
pendek dan mengabaikan keuntungan jangka panjang manajemen. Hal ini dapat dilihat dari perspektif teori agensi. Hasil penelitian Rahayu (2010) menunjukkan nilai perusahaan (Tobin's Q) dipengaruhi oleh independensi dewan komisaris $\mathrm{H}_{4}$ : Komisaris independen berpengaruh terhadap nilai perusahaan

Pelaksanaan CSRberperan penting dalam meningkatkan nilai perusahaan, sebagai hasil dari peningkatan penjualan dan profitabilitas melalui loyalitas konsumen yang terbangun dengan cara pelaksanaan kegiatan sosial di lingkungannya. Epstein dan Friedman (1994) menemukan bahwa investor individual saat ini lebih tertarik terhadap informasi sosial yang dilaporkan dalam laporan tahunan. Investor tidak hanya menggunakan infomasi ekonomi dalam pengambilan keputusan investasi.

$\mathrm{H}_{5}$ : CSR berpengaruh terhadap nilai perusahaan

Pelaksanaan CSR berperan penting dalam meningkatkan nilai perusahaan, sebagai hasil dari peningkatan penjualan dan profitabilitas melalui loyalitas konsumen yang terbangun dengan cara pelaksanaan kegiatan sosial di lingkungannya. Epstein dan Friedman (1994) menemukan bahwa investor individual saat ini lebih tertarik terhadap informasi sosial yang dilaporkan dalam laporan tahunan. Investor tidak hanya menggunakan infomasi ekonomi dalam pengambilan keputusan investasi. Pihak manajerial dalamsuatu perusahaan adalah pihak yang secara aktifberperan aktif dalam pengambilan keputusanuntuk menjalankan perusahaan. Pihak-pihaktersebut adalah mereka yang duduk di dewankomisaris dan dewan direksi perusahaan. Komisaris independen merupakan posisi terbaik untuk melaksanakan fungsi monitoring agar tercipta perusahaan 
yang GCG. Komisaris independen adalah komisaris yang bukan merupakan anggota manajemen, pemegang saham mayoritas, pejabat atau dengan kata lain berhubungan langsung atau tidak langsung dengan pemegang saham mayoritas suatu perusahaan yang mengawasi pengelolahan perusahaan (Alfinur, 2016)

$\mathrm{H}_{6}$ : Kepemilikan manajerial dan komisaris independen berpengaruh terhadap nilai perusahaan melalui CSR

\section{METODE PENELITIAN}

Objek penelitian ini adalah perusahaan tambang yang terdaftar di Bursa Efek Indonesia periode tahun 2016-2017. Jenis data yang digunakan dalam penelitian ini adalah data kuantitatif . Sumber data penelitian ini adalah data sekunder. Populasi dalam penelitian ini adalah 41 perusahaan tambang yang listing di Bursa Efek Indonesia periode 2016-2017. Dalam pengambilan sampel metode yang digunakan adalah purposive sampling. Purposive sampling merupakan pengambilan sample yang dilakukan dengan menggunakan kriteria-kriteria tertentu. Adapun kriteria sample dalam penelitian ini adalah sebagai berikut : 1) Perusahaan tergolong dalam perusahaan pertambangan yang terdaftar di BEI periode 2016-2017. 2) perusahaan yang menyajikan laporan keuangan tahunan dengan lengkap per 31 Desember 2016-2017. 3) perusahaan yang menyajikan laporan CSR periode 2016-2017. Berdasarkan penjelasan tersebut, jumlah pengamatan dalam penelitian ini adalah sebanyak 18 perusahaan pertambangan.

Teknik pengumpulan data yang digunakan dalam penelitian ini adalah dokumentasi yaitu dengan mengumpulkan data-data yang ada. Penelitian ini 
dianalisis dengan menggunakan analisis jalur dengan alat analisis yaitu SPSS versi 23. Model strukturalnya adalah sebagai berikut :

$\mathrm{CSR}=\alpha+\beta_{1} \mathrm{KM}+\beta_{2} \mathrm{KI}+\varepsilon$

$\mathrm{NP}=\alpha+\beta_{4} \mathrm{CSR}+\beta_{1} \mathrm{KM}+\beta_{2} \mathrm{KI}+\varepsilon$

Dimana :

KM : Kepemilikan manajerial

KI : Komisaris Independen

CSR : Corporate Social Responsibility

NP : Nilai Perusahaan

$\varepsilon \quad$ : error

Kedua persamaan diatas digunakan untuk menguji hubungan model mediasi. Untuk membuktikan mediasi harus memenuhi syarat sebagai berikut (Baron \& Kenny, 1986) Variabel independen harus mempengaruhi variabel mediator pada persamaan regresi 1 . Variabel mediator harus mempengaruhi variabel dependen pada persamaan 2.

Jika semua syarat tersebut terpenuhi, pengaruh independen variabel terhadap variabel dependen harus lebih kecil pada persamaan 3 daripada persamaan 2. Mediasi penuh terjadi jika variabel independen tidak berpengaruh ketika variabel mediator sebagai variabel kontrol.

Variabel dependen dalam penelitian ini adalah CSR dan nilai perusahaan. Pengukuran tingkat pengungkapan Y1 yaitu CSR dalam penelitian ini dengan Corporate Social Responsibility Index (CSRI) mengikuti standar GRI (Global Reporing Initiative), dimana terdapat 78 item pengungkapan. Rumus pengungkapan CSR adalah sebagai berikut:

$$
C S D I j=\stackrel{\Sigma X i j}{ }
$$


Keterangan :

$\mathrm{CSDIj}=$ Corporate Social ResponsibilityIndex perusahaan $\mathrm{j}$

$\mathrm{Xij}=$ Jumlah skor item, $1=$ jika item diungkapkan, $0=$ jika itrm I tidak diungkapkan

nij $=$ Jumlah item maksimal untuk perusahaan $\mathrm{j}, \mathrm{n}=78$

Variabel Y2 Nilai perusahaan bisa dilihat dari nilai pasar atau nilai buku perusahaan dari ekuitasnya, Penelitian ini mengacu pada penelitian Cahaya Nugrahani (2012) yangmenggunakan Tobin's $Q$ untuk mengukur nilai perusahaan. Adapun rumusnya sebagai berikut :

$$
\mathrm{Q}=\frac{M V E+D}{B V E+D}
$$

Keterangan :

\section{Q : Nilai perusahaan}

MVE :Nilai Pasar Ekuitas (Ekuity Market Value), diperoleh dengan harga saham penutupan dikalikan dengan jumlah saham yang beredar

D :Nilai buku dari total hutang

BVE :Nilai buku dari total ekuitas (Ekuity Book Value), yang diperoleh dari selisih total asset perusahaan dengan total kewajiban

Variabel X1 kepemilikan manajerial Kepemilikan manajemen diukur menggunakan skala rasio melalui persentasi jumlah saham yang dimiliki manajemen dari seluruh modal perusahaan yang beredar .

\footnotetext{
Saham yang dimiliki manajemen

$\mathrm{KM}=$

Jumlah saham yang beredar

Variabel X2 komisaris independen ) Komisaris Independen diberi symbol KI dan diukur dengan menggunakanindikator persentase anggota dewan komisaris yang berasal dari luarperusahaan (independen) dengan total anggota dewan
} 
komisaris.Proporsi komisaris independen dalam perusahaan diukur dengan skala rasio antara jumlah anggota komisaris independen dibandingkan dengan jumlah anggota dewan komisaris yang ada di perusahaan (Okctavia dan Arifin, 2013). Dengan rumus sebagai berikut :

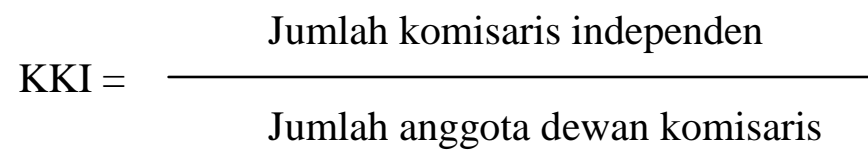

Uji asumsi klasik dilakukan untuk mengetahui dan menguji kelayakan atas model regresi yang digunakan dalam model ini. Uji asumsi klasik yang digunakan dalam penelitian ini adalah uji normalitas, heteroskedastisitas dan autokorelasi. Uji normalitas digunakan untuk mengetahui persamaan regresi yang mempunyai distribusi normal atau tidak.

\section{HASIL PENELITIAN}

Deskripsi Variabel penelitian adalah bagian yang berguna untuk mengambarkan tingkat masing-masing variabel baik variabel bebas dan variabel terikat. Analisis statistik deskriptif digunakan untuk mengetahui deskripsi suatu data yang terdiri dari nilai maxsimum, nilai minimum, mean, dan nilai standar deviation. Berdasarkan hasil olah data analisis statistik deskriptif diperoleh dari penelitian ini

\begin{tabular}{lllll}
\hline N & Minimum & Maximum & Mean & Std. Deviation \\
\hline
\end{tabular}

adalah sebagai berikut:

Tabel 1.

Uji Deskriptif Variabel Penelitian 


\begin{tabular}{lrrrrr}
\hline KM & 36 &, 02 & 2,11 &, 3875 &, 62849 \\
KI & 36 &, 25 & 1,00 &, 4328 &, 13744 \\
CSR & 36 &, 02 &, 36 &, 1753 &, 08911 \\
NP & 36 &, 66 & 5,35 & 2,0808 & 1,12014 \\
Valid N (listwise) & 36 & & & & \\
\hline
\end{tabular}
Sumber : Data diolah, 2017

Berdasarkan table statistik deskriptif di atas menunjukkan jumlah data setiap variabel yang valid adalah 36. Dari 36 data ini menunjukkan variabel pertama adalah kepemilikan manajerial dengan nilai maksimum 2,11 dan nilai minimum adalah 0,2. Rata-rata kepemilikan manajerial dari 36 data adalah 0,3875 dengan standar deviasi sebesar 0,6285. Variabel kedua adalah komisaris independen dengan nilai maksimum 1,00 dan nilai minimum adalah 0,25. Ratarata komisaris independen dari 36 data adalah 0,4328 dengan standar deviasi 0,1374. Variabel ketiga adalah CSR dengan nilai maksimum 0,36 dan nilai minimum adalah 0,02. Rata-rata CSR dari 36 data adalah 0,1753 dengan standar deviasi 0,0891. Variabel keempat adalah nilai perusahaan dengan nilai maksimum 0,66 dan nilai minimum 0,36. Rata-rata nilai perusahaan dari 36 data adalah 2,0808 dengan standar deviasi 1,1201.

Tabel 2.

Hasil Uji One-Sample Kolmogorov-Smirnov

\begin{tabular}{|c|c|c|c|}
\hline & & & $\begin{array}{l}\text { Unstandardized } \\
\text { Residual }\end{array}$ \\
\hline $\mathrm{N}$ & & & 36 \\
\hline \multirow{2}{*}{ Normal Parameters ${ }^{\mathrm{a}, \mathrm{b}}$} & Mean & & ,0000000 \\
\hline & Std. Deviation & & 1,10398668 \\
\hline \multirow[t]{3}{*}{ Most Extreme Differences } & Absolute & & ,171 \\
\hline & Positive & &, 171 \\
\hline & Negative & &,- 094 \\
\hline Test Statistic & & &, 171 \\
\hline Asymp. Sig. (2-tailed) & & &, $009^{\mathrm{c}}$ \\
\hline \multirow[t]{4}{*}{ Monte Carlo Sig. (2-tailed) } & Sig. & & $220^{\mathrm{d}}$ \\
\hline & $99 \%$ Confidence Interval & Lower & 210 \\
\hline & & Bound & ,210 \\
\hline & & Upper Bound & 231 \\
\hline
\end{tabular}

Sumber : Data diolah, 2017 
Uji normalitas bertujuan untuk menguji apakah dalam model regresi,

\begin{tabular}{llrrrrrrr}
\hline & & \multicolumn{2}{c}{$\begin{array}{c}\text { Unstandardized } \\
\text { Coefficients }\end{array}$} & \multicolumn{2}{c}{$\begin{array}{c}\text { Standardized } \\
\text { Coefficients }\end{array}$} & \multicolumn{3}{c}{ Collinearity Statistics } \\
Model & \multicolumn{1}{c}{ B } & Std. Error & Beta & \multicolumn{1}{c}{ t } & Sig. & Tolerance & VIF \\
\hline 1 & (Constant) & 1,254 &, 880 & & 1,425 &, 164 & & \\
& KM &,- 011 &, 324 &,- 006 &,- 033 &, 974 &, 919 & 1,088 \\
& KI & 1,309 & 1,512 &, 161 &, 866 &, 393 &, 882 & 1,134 \\
& CSR & 1,511 & 2,328 &, 120 &, 649 &, 521 &, 885 & 1,130 \\
\hline
\end{tabular}

variabel pengganggu atau residual memiliki distribusi normal. Besarnya nilai Test

Statistic Kolmogorov-Smirnov adalah 0,171 dan tidak signifikan pada 0,210. Hal ini berarti $\mathrm{H} 0$ diterima yang berarti data residual terdistribusi normal.

Tabel 3.

Sumber : Data diolah, 2017

\section{Tabel Koefisien Uji Multikolinieritas}

Uji multikolinieritas bertujuan untuk menguji apakah model regresi ditemukan adanya korelasi antar variabel bebas (Ghozali, 2011). Dari tabel di atas menunjukkan tidak ada variabel independen yang memiliki nilai tolerance kurang dari 0,10 yang berarti tidak ada korelasi antar variabel independen yang nilainya lebih dari 95\%. Hasil perhitungan nilai variance inflation factor juga menunjukkan hal yang sama tidak ada satu variabel independen yang memiliki nilai VIF lebih dari 10. Jadi dapat disimpulkan bahwa tidak ada multikolonieritas antar variabel independen dalam model regresi.

Tabel 4.

Tabel Koefisien Uji Heteroskedastisitas

\begin{tabular}{|c|c|c|c|c|c|c|}
\hline \multirow[b]{2}{*}{ Mod } & & \multicolumn{2}{|c|}{ Unstandardized Coefficients } & \multirow{2}{*}{$\begin{array}{c}\text { Standardized } \\
\text { Coefficients } \\
\text { Beta } \\
\end{array}$} & \multirow[b]{2}{*}{$\mathrm{T}$} & \multirow[b]{2}{*}{ Sig. } \\
\hline & & $\mathrm{B}$ & Std. Error & & & \\
\hline \multirow[t]{4}{*}{1} & (Constant) & ,348 & ,528 & & ,658 & ,515 \\
\hline & KM &,- 142 & , 194 &,- 132 &,- 732 & ,470 \\
\hline & KI & 1,010 & 907 & 204 & 1,113 & 274 \\
\hline & CSR &, 731 & 1,397 & ,096 &, 523 & 604 \\
\hline
\end{tabular}


Uji heteroskedastisitas bertujuan untuk menguji apakah dalam model regresi terjadi ketidaksamaan variance dari residual satu pengamatan ke pengamatan lain. Dari tabel di atas menunjukkan bahwa tidak ada satupun variable independen yang signifikan secara statistik mempengaruhi variabel dependen nilai Absolut. Hal ini terlihat dari probabilitas signifikansinya di atas tingkat kepercayaan 5\%. Jadi dapat disimpulkan model regresi tidak mengandung adanya heteroskedastisitas.

Tabel 5.

Tabel Koefisien Uji Autokorelasi Model Summary ${ }^{\text {b }}$

\begin{tabular}{lrrrrr}
\hline Model & R & R Square & $\begin{array}{c}\text { Adjusted R } \\
\text { Square }\end{array}$ & $\begin{array}{c}\text { Std. Error of the } \\
\text { Estimate }\end{array}$ & Durbin-Watson \\
\hline 1 &, $169^{\mathrm{a}}$ &, 029 &,- 062 & 1,15458 & 1,834 \\
\hline
\end{tabular}

Sumber : Data diolah, 2017

Uji autokorelasi bertujuan untuk menguji apakah dalam suatu model regresi ada korelasi antara kesalahan pengganggu pada periode saat ini $(\mathrm{t})$ dengan kesalahan pada periode sebelumnya (t-1) (Ghozali, 2016). Dari table di atas menunjukkan nilai Durbin-Watson sebesar 1,834 dengan sampel 36 dan variable bebas (k) adalah 4, didapat nilai $\mathrm{dl}=1,236$ dan nilai $\mathrm{du}=1,724$. Oleh karena nilai DW 1,834 lebih besar dari batas atas (du) 1,724 dan kurang dari 4 - 1,724 (4 1,724), maka dapat disimpulkan bahwa tidak terdapat autokorelasi Model struktur pertama dalam penelitian ini adalah sebagai berikut :

$\mathrm{CSR}=\alpha+\beta_{1} \mathrm{KM}_{1}+\beta_{2} \mathrm{KI}_{2+\varepsilon}$

Dari hasil pengolahan data dalam program SPSS versi 23 struktur pertama tersebut, diperoleh hasil output data sebagai berikut:

Tabel 6.

Tabel Hasil Uji Hipotesis 


\begin{tabular}{lrrrrr}
\multicolumn{7}{c}{ Model Summary $^{\mathbf{b}}$} \\
\hline Model & R & R Square & \multicolumn{1}{c}{$\begin{array}{c}\text { Adjusted R } \\
\text { Square }\end{array}$} & $\begin{array}{l}\text { Std. Error of } \\
\text { the Estimate }\end{array}$ & Durbin-Watson \\
\hline 1 &, $339^{\text {a }}$ &, 115 &, 061 &, 08633 & 1,078
\end{tabular}

Sumber : Data diolah, 2017

Dari tabel di atas menunjukkan besarnya nilai Adjusted R Square sebesar 0,061. Nilai ini menerangkan besarnya peran atau kontribusi variabel independen kepemilikan manajerial dan komisaris independen mampu menjelaskan pengungkapan CSR hanya sebesar 6,1 \% sedangkan sisanya dijelaskan oleh variabel di luar model.

Tabel 7.

Tabel Koefisien Uji F

ANOVA $^{\mathrm{a}}$

\begin{tabular}{|c|c|c|c|c|c|c|}
\hline \multirow{2}{*}{$\begin{array}{l}\text { Model } \\
1\end{array}$} & & Sum of Squares & $\mathrm{df}$ & Mean Square & $\mathrm{F}$ & Sig. \\
\hline & Regression & ,032 & 2 & 016 & 3,142 &, $003^{b}$ \\
\hline & Residual & ,246 & 33 & ,007 & & \\
\hline & Total & ,278 & 35 & & & \\
\hline
\end{tabular}

Sumber: Data diolah, 2017

Hasil uji $\mathrm{F}$ menunjukkan nilai $\mathrm{F}$ hitung sebesar 3,142 lebih besar dari $\mathrm{F}$ tabel 2,69 dan nilai probabilitas 0,003 lebih kecil dari signifikansi 0,05 one tile. Hal ini menunjukkan bahwa kepemilikan manajerial dan komisaris independen berpengaruh secara simultan.

Tabel 8.

Tabel Koefisien Uji T Coefficients $^{\mathrm{a}}$

\begin{tabular}{|c|c|c|c|c|c|c|}
\hline \multirow[b]{2}{*}{ Mod } & & \multicolumn{2}{|c|}{ Unstandardized Coefficients } & $\begin{array}{l}\text { Standardized } \\
\text { Coefficients }\end{array}$ & \multirow[b]{2}{*}{$\mathrm{T}$} & \multirow[b]{2}{*}{ Sig. } \\
\hline & & $\mathrm{B}$ & Std. Error & Beta & & \\
\hline \multirow[t]{3}{*}{1} & (Constant) & ,257 & ,048 & & 5,338 & ,000 \\
\hline & KM &,- 023 &, 024 &,- 166 &,- 984 &, 332 \\
\hline & $\mathrm{KI}$ &,- 168 & 109 &,- 260 & $-1,542$ & 133 \\
\hline
\end{tabular}

Sumber : Data diolah, 2017

Dari hasil output regresi tampak bahwanilai untuk variabel independensi kepemilikan manajerial dengan $\mathrm{t}$ statistik sebesar 0,984 dan berarah negatif lebih 
kecil dari t tabel sebesar 1,697 dan tidak signifikan terhadap $\alpha 0,05$ one tiled. $\mathrm{T}$ statistik untuk variabel komisaris independen sebesar 1,542 berarah negatif lebih kecil daripada nilai t hitung sebesar 1,697 dan dengan probabilitas lebih besar dari taraf signifikansi 0,05 (tidak signifikan). Hal ini menunjukkan bahwa kepemilikan manajerial dan komisaris independen tidak berpengaruh terhadap CSR.

Model struktur kedua dalam penelitian ini adalah sebagai berikut :

$\mathrm{NP}=\alpha+\beta_{4} \mathrm{CSR}+\beta_{1} \mathrm{KM}+\beta_{2} \mathrm{KI}+\varepsilon$

Tabel 9.

Tabel Hasil Uji Koefisien Determinasi Struktur Kedua Model Summary ${ }^{\mathrm{b}}$

\begin{tabular}{lccccrr}
\hline Model & $\mathrm{R}$ & $\mathrm{R}$ Square & $\begin{array}{c}\text { Adjusted } \mathrm{R} \\
\text { Square }\end{array}$ & $\begin{array}{c}\text { Std. Error of the } \\
\text { Estimate }\end{array}$ & Durbin-Watson \\
\hline 1 &, $169^{\text {a }}$ &, 029 &,- 062 & 1,15458 & 1,834 \\
\hline Sumber : Data diolah, 2017 & & & & &
\end{tabular}

Dari tabel di atas menunjukkan besarnya nilai Adjusted R Square sebesar $6,2 \%$. Nilai ini menerangkan besarnya peran atau kontribusi variabel independen kepemilikan manajerial, komisaris independen dan CSR mampu menjelaskan nilai perusahaan hanya sebesar $6,2 \%$ sedangkan sisanya dijelaskan oleh variabel di luar model.

Tabel 10.

Tabel hasil Uji F struktur kedua ANOVA $^{\mathrm{a}}$

\begin{tabular}{llrrrrr}
\hline Model & & Sum of Squares & df & Mean Square & F & \multicolumn{1}{c}{ Sig. } \\
\hline 1 & Regression & 1,257 & 3 &, 419 & 0,314 & $\pi^{\mathrm{b}}{ }^{\mathrm{b}}$ \\
& Residual & 42,658 & 32 & 1,333 & & \\
& Total & 43,915 & 35 & & & \\
\hline
\end{tabular}

Sumber: Data diolah, 2017

Hasil uji $\mathrm{F}$ menunjukkan nilai $\mathrm{F}$ hitung sebesar 0,314 lebih kecil dari $\mathrm{F}$ tabel 2,69 dan nilai probabilitas 0,814 lebih besar dari signifikansi 0,05 one tile. Hal ini menunjukkan bahwa kepemilikan manajerial, komisaris independen dan CSR tidak berpengaruh secara simultan. 
Tabel 11.

Tabel Hasil Uji T Struktur Kedua Coefficients $^{\mathbf{a}}$

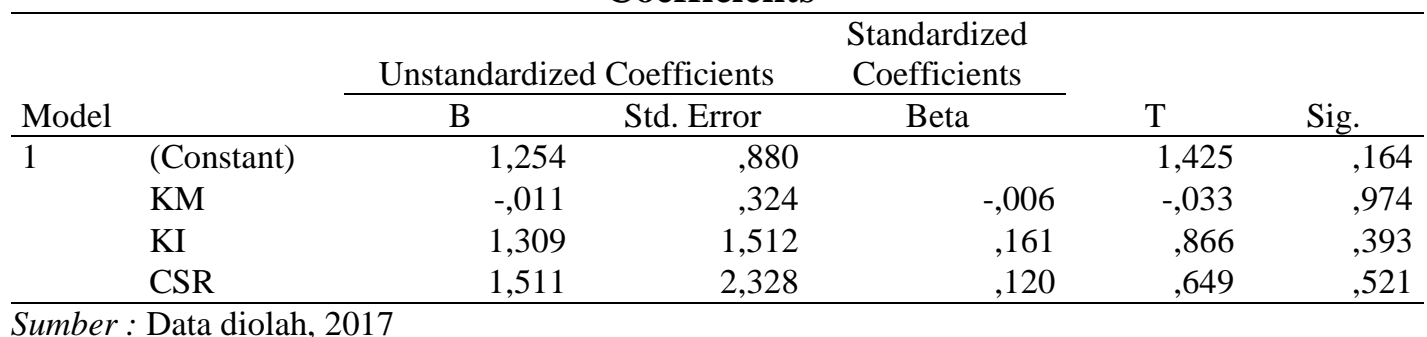

Dari hasil output regresi tampak bahwa nilai untuk variabel independensi kepemilikan manajerial dengan t statistik sebesar 0.033 dan berarah negatif lebih kecil dari t tabel sebesar 1,697 dan tidak signifikan terhadap $\alpha 0,05$ one tiled. $\mathrm{T}$ statistik untuk variabel komisaris independen sebesar 0,866 berarah positif lebih kecil daripada nilai t hitung sebesar 1,697 dan dengan probabilitas lebih besar dari taraf signifikansi 0,05 (tidak signifikan). T statistik untuk variabel CSR sebesar 0,649 berarah positif lebih kecil daripada nilai t hitung sebesar 1,697 dan dengan probabilitas lebih besar dari taraf signifikansi 0,05.Hal ini menunjukkan bahwa kepemilikan manajerial, komisaris independen dan CSR tidak berpengaruh terhadap nilai perusahaan secara parsial.

Analisis jalur merupakan penggunaan analisis regresi untuk menaksir hubungan kausalitas antar variabel yang telah ditetapkan sebelumnya berdasarkan teori (Ghozali, 2016) 
Dari tabel di atas menunjukkan nilai standardized beta kepemilikan manajerial pada persamaan 1 sebesar -0,166 dan tidak signifikan pada 0,332 yang berarti kepemilikan manajerial tidak mempengaruhi CSR. Nilai standardized beta komisaris independen pada persamaan 1 sebesar -0,260 dan tidak signifikan pada 0,133 yang berarti komisaris independen tidak mempengaruhi CSR. Nilai koefisien standardized beta kepemilikan manajerial dan komisaris independen merupakan nilai path atau jalur p2. Pada hasil olah SPSS persamaan regresi (2) nilai standardized beta untuk kepemilikan manajerial adalah $-0,006$, komisaris independen adalah 0,161 dan CSR adalah 0,120. Semuanya tidak signifikan. Nilai standardized beta kepemilikan manajerial dan komisaris independen $-0,006$ dan dan 0,161 merupakan nilai jalur path $\mathrm{p} 1$ dan nilai standardized beta CSR 0,120 merupakan nilai jalur path p3. Besarnya nilai e1 $=$

Dari tabel persamaan 1 dan 2 menunjukkan bahwa nilai beta kepemilikan manajerial adalah -0,166 dengan nilai signifikan 0,332 besar dari 0,05. Dapat disimpulkan bahwa kepemilikan manajerial tidak berpengaruh terhadap CSR. Dengan kepemilikan manajerial yang relatif sangat kecil, maka masih terjadi konflik kepentingan antara pemilik dengan manajer, dimana kepentingan pribadi manajer belum dapat diselaraskan dengan kepentingan perusahaan oleh pemilik. Hasil penelitian ini sejalan dengan penelitian yang dilakukan oleh Wien Ika Permana Sari (2010) dan Ramdhaningsih dan Utama (2013) yang menunjukkan bahwa kepemilikan manajerial tidak berpengaruh terhadap CSR

Dari tabel persamaan 1 dan 2 menunjukkan bahwa nilai beta komisaris independen adalah -0,260 dengan nilai signifikan 0,133 besar dari 0,05. Dapat 
disimpulkan bahwa komisaris independen tidak berpengaruh terhadap CSR. Hal ini bisa saja dikarenakan tingkat independensi dewan komisaris masih dipertanyakan sehingga fungsi pengawasan tidak berjalan dengan baik. Hasil penelitian ini sejalan dengan penelitian yang dilakukan oleh Ramdhaningsih dan Utama (2013) yang menunjukkan bahwa komisaris independen tidak berpengaruh terhadap CSR.

Dari tabel persamaan 1 dan 2 menunjukkan bahwa nilai beta kepemilikan manajerial adalah -0,006 dengan nilai signifikan 0,974 besar dari 0,05. Dapat disimpulkan bahwa kepemilikan manajerial tidak berpengaruh terhadap nilai perusahaan. Di Indonesia kepemilikan manajerial masih sangat rendah sehingga para investor merasa ragu untuk melakukan investasi dan tentunya akan berpengaruh terhadap nilai perusahaan. Hasil penelitian ini sejalan dengan penelitian yang dilakukan oleh Nurfaza (2017) yang menunjukkan bahwa kepemilikan manajerial tidak berpengaruh terhadap Nilai perusahaan

Dari tabel persamaan 2 menunjukkan bahwa nilai beta komisaris independen adalah 0,161 dengan nilai signifikan 0,393 besar dari 0,05. Dapat disimpulkan bahwa komisaris independen tidak berpengaruh terhadap nilai perusahaan. Hal ini bisa saja karena pengawasan yang dilakukan oleh komisaris independen dalam perusahaan belum maksimal sehingga belum mampu meningkatkan nilai perusahaan. Hasil penelitian ini sejalan dengan penelitian yang dilakukan oleh Nurfaza (2017) yang menunjukkan bahwa komisaris indepeden tidak berpengaruh terhadap Nilai perusahaan. 
Dari tabel persamaan 2 menunjukkan bahwa nilai beta komisaris independen adalah -0,120 dengan nilai signifikan 0,521 besar dari 0,05. Dapat disimpulkan bahwa CSR tidak berpengaruh terhadap nilai perusahaan. Hal ini bisa saja karena pengungkapan CSR pada suatu perusahaan rendah sehingga pengungkapan CSR tidak berpengaruh terhadap nilai perusahan. Hasil penelitian ini sejalan dengan penelitian yang dilakukan oleh Mutmainnah (2015) yang menunjukkan bahwa CSR tidak berpengaruh terhadap nilai perusahaan.

\section{SIMPULAN}

Dari hasil pembahasan di atas maka kesimpulan yang bisa di ambil adalah sebagai berikut Secara simultan penelitian ini menunjukkan bahwa kepemilikan manajerial dan komisaris independen memiliki pengaruh terhadap pengungkapan CSR. Secara simultan penelitian ini menunjukkan bahwa kepemilikan manajerial, komisaris independen dan CSR tidak memiliki pengaruh terhadap nilai perusahaan. Secara parsial penelitian ini menunjukkan bahwa kepemilikan manajerial tidak memiliki pengaruh terhadap CSR maupun nilai perusahaan. Secara parsial penelitian ini menunjukkan bahwa komisaris independen tidak memiliki pengaruh terhadap CSR maupun nilai perusahaan

Penelitian ini hanya menggunakan perusahaan tambang sebagai sampel penelitian. Untuk penelitian selanjutnya bisa memperluas sampel dengan memperluas jenis perusahaan. Periode waktu penelitian hanya dua tahun. Untuk penelitian selanjutnya bisa menambah periode waktu penelitian agar hasil yang di dapatkan lebih baik. 


\section{REFRENSI}

Amanti, L. 2012. Pengaruh Good Corporate Governance Terhadap Nilai Perusahaan dengan Pengungkapan Corporate Sosial Responsibility sebagai Variabel Pemoderasi pada Perusahaan Rokok yang Terdaftar di $B E I$. Unpublished Undergraduate Thesis.Universitas Negeri. Surabaya.

Alfinur (2016). Pengaruh Mekanisme Good Corporate Governance (GCG) Terhadap Nilai Perusahaan Pada Perusahaan yang Listing di BEI. Jurnal Ekonomi Modernisasi (JEM) Vol. 12, No. 1, pp: 44-50. ISSN: 2502-4078

Badjuri, Acmat. 2011. Faktor-faktor Yang Berpengaruh Terhadap Kualitas Audit Auditor Independen Pada Kantor Akuntan Publik (KAP) Di Jawa Tengah. Dinamika Keuangan dan Perbankan, Nopember 2011, Volume 3, Nomor 2.

Barako, D. G., Hancock, P. \& Izan, H. 2006. Factors influencing voluntary corporate disclosure by Kenyan companies. Corporate Governance: An International Review, 14:2, 107-25.

Epstein, M. J., dan Freedman, M. (1994). Social disclosure and the individual investor. Accounting, Auditing and Accountability Journal. Vol. 7: 94-109.

Ghozali, I. (2014). Analisis Multivariat dan Ekonometrika. Semarang: Universitas Diponegoro.

Herawaty, Vinola. 2008. Peran Praktek Corporate Governance Sebagai Moderating Variabel dari Pengaruh Earning Management Terhadap Nilai Perusahaan. Jurnal Akuntansi dan Keuangan,Vol. 10 No. 2, November, 2008, hal: 97-108.

Jensen, Michael C. Dan W.H. Meckling. (1976). "Theory of The Firm: Managerial Behavior, Agency Cost and Ownership Structure”. Journal of Financial Economics 3. hal. 305-360.

Kilat Liliani Ningtyas, Suhadak, dan Nila Firdausi Nuzula. 2014. Pengaruh Good Corporate Governance Terhadap Nilai Perusahaan (Studi pada Perusahaan yang Terdaftar di Jakarta Islamic Index tahun 2010-2013). Jurnal Administrasi Bisnis (JAB) Vol 17 No 1PP: 1-9

Lindawati, A. S. L., \& Puspita, M. E. (2015). Corporate Social Responsibility: Implikasi Stakeholder dan Legiti macy Gap dalam Peningkatan Kinerja Perusahaan. Jurnal Akuntansi Multiparadigma, 6(1), 157-174. 
Marius, Mauren Erna dan Masri,Indah. (217). Pengaruh Good Corporate Govarnance dan Corporate Social Responsibility terhadap Nilai Perusahaan .Konferensi Ilmiah Akuntansi IV

Nicolin, Octavia dan Arifin Sabeni. 2013. "Pengaruh Struktur Corporate Governance, audit tenure, dan spesialisasi Industri Auditor terhadap Integritas Laporan Keuangan. Diponegoro Journal of Accounting Vol 2 No3 2013 1-12. ISSN

Putri dan Christiawan. 2014. Pengaruh Profitabilitas, Likuiditas dan Leverage terhadap Pengungkapan Corporate Social Responsibility Bussines Accouting Review . Vol 2. No 1. 2014

Permanasari, Wien Ika. 2010. Pengaruh Kepemilikan Manajerial, Kepemilikan Institusional, dan Corpotate Social Responsibility Terhadap Nilai Perusahaan. Skripsi. Fakultas Ekonomi Universitas Diponegoro.

Priantana, Riha Dedi dan Ade Yustian. 2011. "Pengaruh Struktur Good Corporate Governance Terhadap Pengungkapan Corporate Social Responsibility pada Perusahaan Keuangan yang Terdaftar di Bursa Efek Indonesia".Jurnal Telaah \& Riset Akuntansi, Vol. 4, Hal. 65-78

Rahayu, Sri. 2010. Pengaruh Kinerja Keuangan terhadap Nilai Perusahaan dengan Pengungkapan Corporate Social Responsibility dan Good Corporate Governance sebagau Variabel Pemoderasi. Skripsi. Tidak diterbitkan : UNDIP Fakultas Ekonomi.

Rustiarini, N.W. 2010. Pengaruh GCG pada hubungan CSR dan nilai perusahaan. Simposium Nasional Akuntansi XIII.Purwokerto

Rawi,dan Munawar Muchlis. 2010. "Kepemilikan Manajemen, Kepemilikan Institusi, Leverage dan Corporate Social Responsibility". Simposium Nasional Akuntansi XIII. Purwokerto. 